\title{
HOW DO THE ECB MEETINGS AFFECT THE STOCK VALUATIONS OF FOUR IBEX35 BANKS?
}

\author{
Samer Ajour El Zain ${ }^{1 *}$, Albert Montero ${ }^{2}$, Reza Gheshmi ${ }^{3}$, Cristina Tomas Perez ${ }^{4}$ \\ ${ }^{1 *, 2,3,4}$ Department of Economic and Finance, EAE Business School, Spain. \\ Email: "sajour@eae.es
}

Article History: Received on $17^{\text {th }}$ January 2021, Revised on $5^{\text {th }}$ May 2021, Published on $10^{\text {th }}$ May 2021

\begin{abstract}
Purpose: Analyze the data and draw there were any relevant conclusions between the meetings of the central bank and the movements of the banking corporations in the stock market.

Methodology: To carry out this study, it was necessary to obtain two extremely important data sets (exact dates of the ECB meetings, stock market valuations of the four banking entities understudy). Both were obtained by searching on specialized websites. Then a comparison of the variations, a correlation table, which will allow us to mathematically affirm whether there is a linear relationship and proportionality between the variations of the banks or not, were analyzed.
\end{abstract}

Main Findings: The results obtained indicate that such influence on the part of the European Central Bank on the financial entities listed on the IBEX35 does not exist, since the variations between bank shares are random and maybe would be better explained by other hypotheses or inputs.

Application of Study: This work discards the hypothesis proposed by the student, although it manages to find other interesting relationships between banks because of the correlation analysis carried out in the analysis part of the work.

Novelty/Originality: Establish the relationship between the meetings of the central bank and the movements of the banking corporations in the stock market.

Keywords: ECB, Interest, Correlation, Stock Market.

\section{INTRODUCTION}

Despite the fact that business banks have gradually followed the broadening methodology and profoundly infiltrated into non-conventional organizations for additional pay sources, concentrates on potential expansion benefits give blended outcomes (Vo, X. V. 2017).

Since the financial crisis began in 2008, with the outbreak of subprime mortgages in the United States, and the subsequent contagion to the world economy, the European Central Bank launched a series of measures to try to reactivate the economy of the Euro Zone (BCE. 2014). This paper will try to find out if and how one of these measures, mainly the one related to interest rates affects the price of four of the largest banks listed on the Spanish stock market.

Earlier examinations record an immaterial impact of hidden increases/misfortunes and a negative impact of acknowledged additions/misfortunes on bank stock returns (Ahmed, A. S., \& Takeda, C. 1995).

The main motivation for the development of this specific topic is given by the curiosity that the world of the stock markets has always raised in the student and how the external influences can make the valuations traded in the stock market vary beyond the ratios analysis such as the Price Earnings Ratio (https://www.ecb.europa.eu/ecb/histo ry/html/index.es.html).

It is because of this curiosity that the idea to look for patterns of influence/connection between the decisions made by the European Central Bank and the reactions of the stock market arises, especially in the banking sector, once these are announced. In addition, this interaction is specifically chosen since it is easy to trace because the meetings are periodic and their calendar is public (Schepens, G. 2018, Deia. 2020). Another important factor is that usually the decisions that the Central Bank will make can be anticipated and even filtered to the media before they come into force and that will allow us to analyze the day before the announcements of the decisions (https://www.bde.es/bde/es/secciones/prensa/N otas_y_decision/Decisiones_de_po/index2019.html).

Consequently, the Eurozone economy entered a recession with a sharp fall in GDP in 2009, as seen in the illustration below to mitigate the effects of the economic downturn and stimulate recovery the European Central Bank had to intervene by carrying out a series of measures, including lowering the interest rate.

The European Central Bank was created in June 1998 as the body in charge of managing the Union's monetary policy, but it was not until 2009 with the ratification of the Lisbon Treaty when it acquired the status of an Institution of the European Union (Lacalle, D. 2017, Cinco Días. 2020).

The main tasks of the European Central Bank are to define and execute the monetary policy of the eurozone, direct foreign exchange operations, take care of the international reserves of the European System of Central Banks and promote the proper functioning of the financial market infrastructure. Furthermore, the ECB has the exclusive right to 
authorize the issuance of euro banknotes. Member states can issue euro coins, but the amount must be authorized in advance by the ECB.

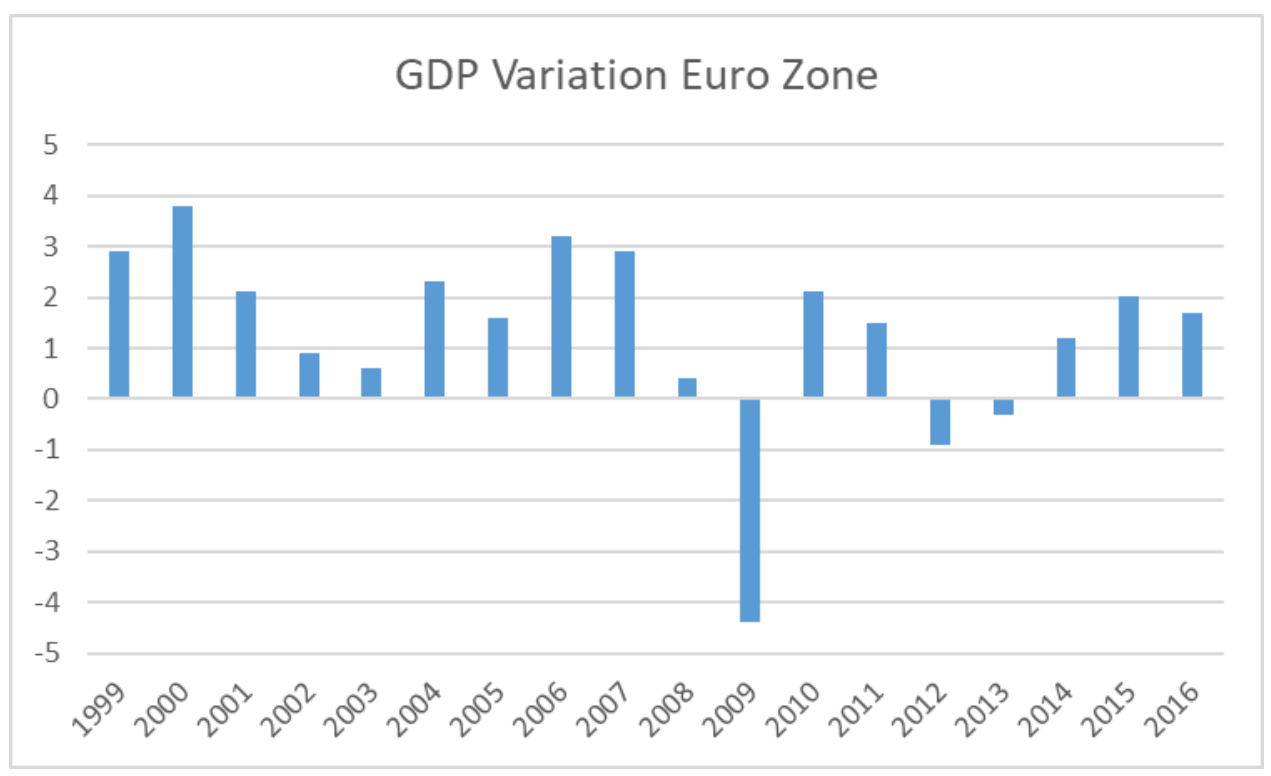

Figure 1: GDP variation eurozone 1999-2016

Who participates in the meetings of the ECB and what is their role?

The main body of the European Central Bank, and the one that makes decisions, is the Governing Council. This Council is made up of 6 members of the Executive Committee and the 19 governors of the central banks of the Eurozone countries.

The Executive Council is responsible for formulating the monetary policies of the Eurozone, specifically:

- Carry out tasks assigned by the ECB and the Euro system (monetary authority of the Euro Zone)

- Formulate the necessary monetary policies, for example by changing interest rates, to keep inflation around $2 \%$ in the medium term. Also, safeguard the Euro system reserves.

Supervision of banks that are under the Unified Supervision System

How does the interest rate affect banks?

The European Central Bank assumes that there is a fundamental problem in the economy's financing credit system, and that is that credit does not flow to companies or families and, therefore, what to do is to let that credit begin to grow in a faster way reducing the cost and increasing the amount of money.

To achieve this, it uses its monetary policy weapons first by lowering interest rates so that economic agents see that each time they are given less for that money they have saved in deposits and therefore try to put it to work. Instead of saving, companies are encouraged to invest because money pays less and less.

Second, increase the money supply, which means artificially creating credit by buying state and corporate debt. States issue sovereign debt that is bought by the European central bank. Therefore, what is a debt for the state for the European central bank is an asset, and the same with companies.

Third, the European central bank trusts that the economy will tend to improve, so it will earn money from the interest paid on these bonds it has bought.

Banks that lend to businesses and families are freed from burdening their sovereign debt balance and by transferring that burden to the ECB, banks can increase credit for small and medium-sized businesses and families.

The main objectives of this investigation are, on one hand, to elucidate what, if any, the impact on the day before the ECB announcements and the reaction of the markets on the day of the announcement. On the other hand, study the joint behavior of the stocks of the banks under study.

All of the above is framed within the ultimate objective, which is to see possible patterns of behavior of investors, and if these can be useful and help when buying and selling shares on dates similar to those studied or if, on the contrary, stock market movements on those dates correspond to other types of hypotheses or inputs. 
Another objective is also to try to clarify if using non-conventional methods, such as the ratios used in the world of finance to analyze companies or sectors can be useful and conclusions can be drawn to help decision-making when making transactions to be more productive or efficient.

\section{LITERATURE REVIEW}

Currently, the studies carried out on the influence of fluctuations in the interest rate set by the ECB on banks have been carried out from the point of view of the gains or losses that this entails for the business of loans and deposits.

Late AML guideline is a cost consistent trouble for banks, where the expenses of activities exceed the advantages of improved cycles (Balani, H. 2019).

It is demonstrated that market valuation measures significantly affect banks' stock costs. Profits per share (DPS), book esteem per offer, and profit yield likewise significantly affected stock cost, while there was no critical impact brought about by EPS, P/E, market/book proportion, or then again stock turnover proportion (Warrad, L. H. 2017). Testing three venture procedures indicated that bank products could be beneficially utilized in portfolio decisions (Forte, G., Gianfrate, G., \& Rossi, E. 2020, Fundssociety. 2019).

It is demonstrated that show that speculators give significantly low market valuations to occupied Shari'ah warning board which goes about as an extra layer of administration in Islamic banks (Elnahass, M., et al. 2019). Confidencedriven financial specialists will in general esteem more adjusting stocks, during seasons of trouble and vulnerability, and in more administrative conditions (Boubakri, N., et al. 2019).

Stress testing has been instructive to the market and that those BHCs that fizzled at the post-emergency stress tests were not hence esteemed contrastingly by the market (Bertsatos, G., Sakellaris, P., \& Tsionas, M. G. 2017). Guarantors are bound to utilize DDM to esteem firms that have a profits payout trail. The speculation banks select DCF while esteeming the more youthful firms, that have more resources in-unmistakable, firms that have negative deals development and positive market returns before the IPO; while tantamount products are utilized for develop firms a lot that have less resources in-substantial (Rasheed, A., et al. 2018, La Voz de Galicia. 2019).

However, studies have been done on how these decisions affect other markets such as currencies and bonds. All the studies found on this subject have emerged from economists working for the ECB, and published on its official website.

The results show us an increase in the stock market valuation of the banks on the days of the meeting,

Since the ECB has been periodically, lowering interest rates and this leads to a drop in profits by part of financial entities in the business of bank loans but at the same time, an opportunity to attract more customers to what is the main business of a bank, loans.

At the same time, we do not expect very high increases given. According to some papers published from the ECB itself, the lower the interest rates the more tendency banks have to seek riskier business alternatives and reduce their percentage of bank deposits since investors could be reluctant to allow banks to take more risks by prioritizing other business lines with more volatility. This would lead shareholders to sell their positions in the banking business.

In short, we expect an increase in the variations, but not in very high proportions.

\section{METHODOLOGY}

To carry out this study, it was necessary to obtain two extremely important data sets, which were the following:

\section{- Exact dates of the ECB meetings}

- Stock market valuations of the four banking entities understudy

Both information were relatively easy to find individually by searching on specialized websites, however, when transferring all the information from a CSV format to an Excel sheet, and thus being able to work with all the grouped data, the first problem arose: only they were able to analyze the value of the shares after April 2, 2012. This was due to errors found in the data sets of some entities in days prior to this date.

It is not convenient to include in the selected data the last two dates of meetings that we have. Since the evaluations of those days are strongly influenced by the outbreak of the health / economic crisis of the COVID-19 pandemic. This pandemic began to be relevant in Spain during the first days of March and required a confinement of the population, which caused a collapse of the IBEX -35 and a forecast of a fall in the Gross Domestic Product unprecedented since the time of the Spanish Civil War (1936-1939).

Once all the data is available, the next step is to relate the dates obtained from the meeting days with all the valuation dates that we had. From this filtering, we make the four groups that we are interested in analyzing:

- Every day of the meeting.

- Every day before the meeting. 
- All the days in which the interest rate has remained stable with respect to the previous meeting.

- All the days in which the interest rate has decreased.

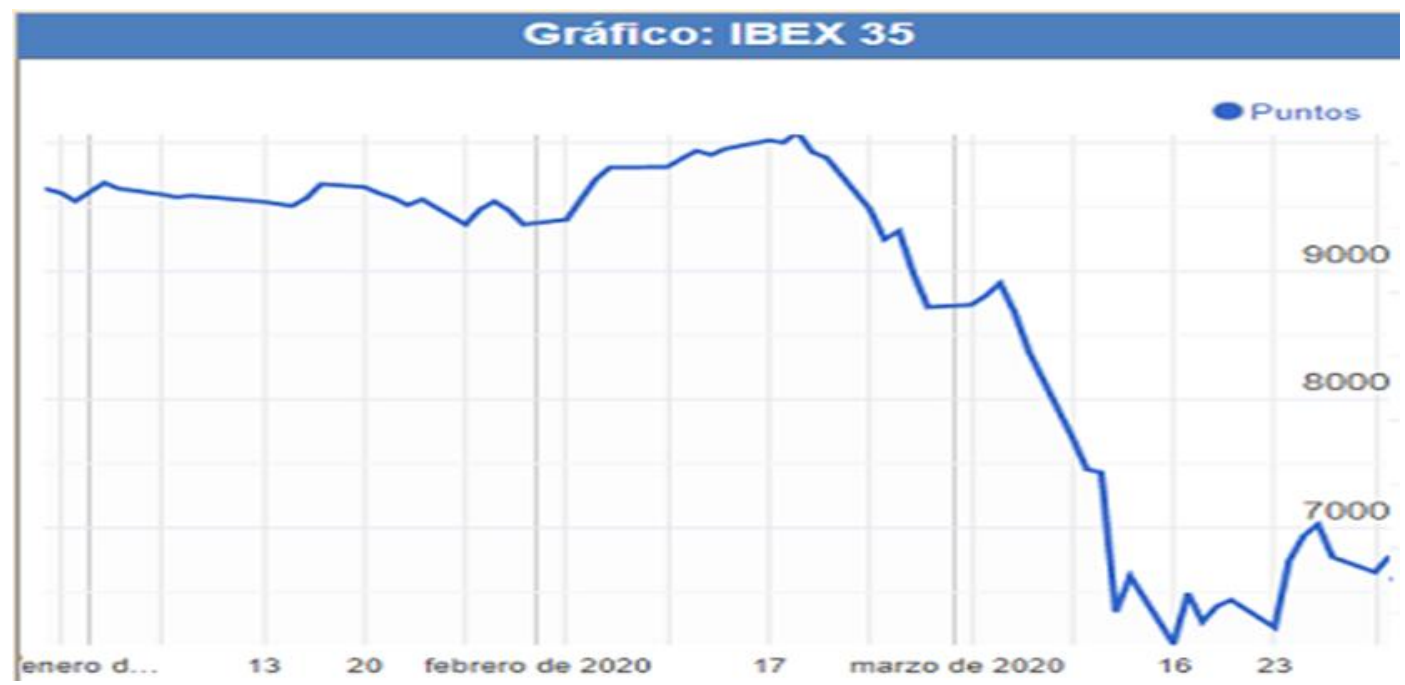

Figure 2: Evolution of the Spanish stock exchange January/march 2020

Source: www.datosmacro.expansion.com

By having the volumes traded for each share, a table will also be made in which the means of the meeting days will be compared with the means of all the days obtained to see if there are differences between them.

Analysis

Three aspects that we believe are key will be analyzed in order to draw conclusions later. These are:

- A comparison of the variations.

- A correlation table, which will allow us to mathematically affirm whether there is a linear relationship and proportionality between the variations of the banks or not.

To study the results of the correlation analysis, table. 1 will be used:

Table 1: Correlation analysis

\begin{tabular}{ll}
\hline Coefficient & Interpretation \\
\hline 0 & Null \\
\hline$>0.0-0.2$ & Very low \\
\hline$>0.2-0.4$ & Low \\
\hline$>0.4-0.6$ & Moderate \\
\hline$>0.6-0.8$ & High \\
\hline$>0.8-<1.0$ & Very high \\
\hline 1.0 & Perfect \\
\hline
\end{tabular}

\section{RESULTS AND DISCUSSION}

The analysis of the variations in the day before the meeting shows that of the 74 days prior to the meeting day, 19 present a global positive variation, 14 a negative variation, and 41 present variation discrepancies between the valuations of the four banks.

Thus, it is obtained that in $44.6 \%$ of the days the entities have homogeneous variations, regardless of whether they are positive or negative, and in $53.4 \%$, they present discrepancies between them.

The shares have behaved in a uniform manner except for some deviations, for example, the rise of $11.74 \%$ of the CaixaBank share on January 9, 2013, or the fall of 5.17\% of Banco Sabadell on April 25, 2018.

In table 2, we can see how, of the four banking entities, only the behavior of the Santander and BBVA (2019) shares have a very high correlation with each other. The behaviors of the other actions have a moderate correlation between them. 
Table 2: Correlation table day before the meeting

\begin{tabular}{|c|c|c|c|c|}
\hline & Santander & CaixaBank & BBVA(2019) & Sabadell \\
\hline Santander & 1 & & & \\
\hline CaixaBank & 0,62321004 & 1 & & \\
\hline $\mathrm{BBVA}(2019)$ & 0,8840066 & 0,68745847 & 1 & \\
\hline Sabadell & 0,58263307 & 0,59564764 & 0,63591746 & 1 \\
\hline
\end{tabular}

It is observed that, of the total of 74 days observed, in 28 cases, the four stocks analyzed have had a rise in the value of the share, in another 21 days the value has decreased and in the remaining 25 days, there have been discrepancies in behavior.

Thus, globally, in 49 of the 74 days, the value of all banks has followed the same trend, without taking into account its sign, which represents $66.21 \%$ of the total. Consequently, in the $33.79 \%$ of the remaining days, the shares have operated differently from each other.

As in the previous case, the percentage variations of the banks during the period studied are displayed. We can see how, more or less, the behavior of all the values are quite similar.

Using the Pearson correlation coefficient, we see how the highest correlation we find is between Banco Santander and BBVA (2019), while the lowest is between Banco Santander and Sabadell. Likewise, they all have a high or very high correlation between them.

Table 3: Correlation table Meeting Day

\begin{tabular}{lllll}
\hline & Santander & CaixaBank & BBVA & Sabadell \\
\hline Santander & 1 & & & \\
\hline CaixaBank & 0,84813436 & 1 & & \\
\hline BBVA & 0,93396533 & 0,89030125 & 1 & 1 \\
\hline Sabadell & 0,81231756 & 0,8665986 & 0,83492954 & 1 \\
\hline
\end{tabular}

The analysis shows that the days when the interest rate is maintained 26 of the 68 days, or $38.24 \%$, all values have a positive sign, 20 of 68, 29'41\%, have a negative sign, and the remaining 22 days, which represent $32.35 \%$ have sign differences between their variations.

We have another table of correlations below. It is seen that all the correlations are within what we consider a high correlation.

Table 4: Correlation table day interest rate is maintained

\begin{tabular}{lllll}
\hline & Santander & CaixaBank & BBVA & Sabadell \\
\hline Santander & 1 & & & \\
\hline CaixaBank & 0,73139589 & 1 & & \\
\hline BBVA & 0,874545 & 0,81296183 & 1 & 1 \\
\hline Sabadell & 0,75999707 & 0,81132287 & 0,80437591 & \\
\hline
\end{tabular}

Finally, we find the six days in which the Governing Council of the ECB decided to lower the interest rate. In three of these six days, the response was positive from bank investors, on one occasion it was negative and on the remaining two days, there were discrepancies in the sign of the variation.

If we do the percentages, the days in positive were $50 \%$, in negative $16.67 \%$, and the days in which there were these discrepancies $33.33 \%$

In the analysis of the next table we find an interesting result and is that on one hand we find an almost perfect correlation between the shares of Banco Santander and BBVA (2016) and, on the other, it looks like the Banco Sabadell has the weakest correlations in the table with the other banks.

In general, only with the exception of Banco Sabadell, the other correlations are considered very high.

Table 5: Correlation table day the interest rate decreases

\begin{tabular}{lllll}
\hline & Santander & CaixaBank & BBVA(2019) & Sabadell \\
\hline Santander & 1 & & & \\
\hline CaixaBank & 0,92786604 & 1 & & \\
\hline BBVA(2016) & 0,98538799 & 0,90018933 & 1 & 1 \\
\hline Sabadell & 0,74793627 & 0,92188625 & 0,75522699 & 1 \\
\hline
\end{tabular}

As an extra, we also analyze the data referring to the volumes of transactions for each bank and the type of day that will allow us to know the degree of excitement of investors regarding the shares. For this, we make the average of 
transactions of every day and the average of transactions of the days in which the European Central Bank has had a meeting.

As a result, it is obtained that on the days in which there is a meeting; more shares are traded than on the other days of the period studied.

Table 6: Negotiated volumes for each bank

\begin{tabular}{lllll}
\hline & Santander & CaixaBank & BBVA(2016). & Sabadell \\
\hline Every day of the period & 66,342 & 15,292 & 28,963 & 21,450 \\
\hline Meeting days & 85,138 & 17,708 & 34,768 & 28,945 \\
\hline Difference & 18,796 & 2,416 & 5,805 & 7,494 \\
\hline
\end{tabular}

*in millions

\section{CONCLUSION}

One of the behaviors that can be seen is that the shares of BBVA (2019) and Banco Santander have similar behaviors according to all the results obtained through the correlation table. A possible explanation could be that, since both are the main players in the financial market, the buyers of the shares of one of the two banks also own shares of the other and vice versa, and when the share of one of the two goes down, they sell those of the other or the other way around. Thus, we can define similar investment strategies for the shares of both banks.

It should also be noted that the days in which the interest rate falls are the days in which the shares behave more homogeneously, either rising or falling since they do so in the same sign in $67 \%$ of the shares times.

As a final conclusion, it can be stated that considering the results, another type of more mathematical analysis would be needed for each company individually, to decide what type of strategy to take for each of the entities using, for example, techniques more related to the world of computing and Big Data capable of processing very high amounts of inputs. The markets definitely do not take into account the news or the decisions arising from Frankfurt and fluctuate due to other explanations not found in this document.

\section{LIMITATION OF STUDY}

Once all the results have been obtained, it is demonstrated that there is no evidence of any type of pattern in the behaviour of the actions during days understudy, however, if interesting information can be seen and extracted and that it may be beneficial in case wanting to invest in the purchase/sale of shares.

\section{AUTHORS' CONTRIBUTIONS}

Samer Ajour El Zain:' Collected the information.

Albert Montero: Analyzed the data.

Reza Gheshmi: Wrote the paper and analysed the results.

Cristina Tomas Perez: Wrote the paper.

\section{REFERENCES}

1. Ahmed, A. S., \& Takeda, C. (1995). Stock market valuation of gains and losses on commercial banks' investment securities An empirical analysis. Journal of Accounting and Economics, 20(2), 207-225. https://doi.org/10.1016/0165-4101(95)00396-Z

2. Balani, H. (2019). Assessing the introduction of anti-money laundering regulations on bank stock valuation. Journal of Money Laundering Control. https://doi.org/10.1108/JMLC-03-2018-0021

3. BBVA. (1 de diciembre de 2016). Obtenido de https://www.bbva.com/es/consecuencias-una-bajada-tiposinteres/

4. BBVA. (1 de abril de 2019). Obtenido de https://www.bbva.com/es/como-afectan-los-tipos-bajos-de-interesa-la-rentabilidad-de-la-banca/

5. BCE. (12 de junio de 2014). Banco Central Europeo. Obtenido de https://www.ecb.europa.eu/explainers/tellme-more/html/why-negative-interest-rate.es.html

6. BCE. (s.f.). BCE. Obtenido de https://www.ecb.europa.eu/ecb/history/html/index.es.html

7. Bertsatos, G., Sakellaris, P., \& Tsionas, M. G. (2017). Did the financial crisis affect the market valuation of large systemic US banks?. Journal of Financial Stability,32, 115-123. https://doi.org/10.1016/j.jfs. 2017.09.002

8. Boubakri, N., Chen, R., Guedhami, O., \& Li, X. (2019). The Stock Liquidity of Banks: A Comparison between Islamic and Conventional Banks in Emerging Economies. Emerging Markets Review, 39, 210-224. https://doi.org/10.1016/j.ememar.2019.03.006

9. Cinco Días. (1 de mayo de 2020). Obtenido de https://cincodias.elpais.com/cincodias/2020/04/3 0/mercados/1588245972 643544.html 
10. Deia. (12 de marzo de 2020). Deia. Obtenido de https://www.deia.eus/economia/2020/03/12/bce-mantienetipos-interes-compra/1024236.html

11. Elnahass, M., Omoteso, K., Salama, A., \& Trinh, V. Q. (2019). Differential market valuations of board busyness across alternative banking models. Review of Quantitative Finance and Accounting, 1-38. https://doi.org/10.1007/s11156-019-00841-4

12. España, B. D. (s.f.). BDE. Obtenido de BDE: https://www.bde.es/bde/es/secciones/prensa/Notas_y_d ecision/Decisiones_de_po/index2019.html

13. Forte, G., Gianfrate, G., \& Rossi, E. (2020). Does relative valuation work for banks?. Global Finance Journal, 44, 100449. https://doi.org/10.1016/j.gfj.2018.09.002

14. Fundssociety. (22 de enero de 2019). Obtenido de https://www.fundssociety.com/es/noticias/mercados/asi-esla-agenda-de-reuniones-del-banco-central-europeo-para-2019

15. La voz de Galicia. (18 de octubre de 2019). Obtenido de https://www.lavozdegalicia.es/noticia/contenidospatrocinados/2018/10/24/tipos-interes-repercusion-mercados-financieros/00031540377544026660886.htm

16. Lacalle, D. (26 de Septembre de 2017). Youtube. Obtenido de https://www.youtube.com/watch?v $=\mathrm{xODWNYHOPNw}$

17. Rasheed, A., Khalid Sohail, M., Din, S. U., \& Ijaz, M. (2018). How Do Investment Banks Price Initial Public Offerings? An Empirical Analysis of Emerging Market. International Journal of Financial Studies, 6(3), 77. https://doi.org/10.3390/ijfs6030077

18. Schepens, G. (13 de febrero de 2018). European Central Bank. Obtenido de https://www.ecb.europa.eu/pub/ economic-research/resbull/2018/html/ecb.rb180213.en.html

19. Vo, X. V. (2017). How does the stock market value bank diversification? Evidence from Vietnam. Finance Research Letters, 22, 101-104. https://doi.org/10.1016/j.frl.2017.06.005

20. Warrad, L. H. (2017). The Effect of Market Valuation Measures on Stock Price: An Empirical Investigation on Jordanian Banks. International Journal of Business and Social Science, 8(3), 67-74. 